\title{
Analysis of the Organic Integration Strategy of College Teachers' Basic Party Branch Construction and Talent Training
}

\section{Zihao Li}

Xuchang University, Xuchang 461000, Henan, China.

Fund Project: Xuchang University Party Building and Ideological and Political Work Research Association 2018 Project "Research on the Effectiveness of the Construction of Teachers' Party Branches in Secondary Colleges of Higher Education" (No. DJ-ZD-201808); Xuchang University's 2020 scientific research project “New Era University Basic Party Branch Research on Power Party Building"(No.2020ZX005)

Abstract: Colleges and universities are the main positions for implementing the strategy of "rejuvenating the country through science and education" and "strengthening the country through talents" and cultivating high-quality talents who can realize the needs of the "Chinese Dream". The grassroots party branch of college teachers is the specific implementer of the party building work in colleges and universities. It effectively strengthens the quality of construction and realizes the organic integration of the construction of the grassroots party branch of teachers and the cultivation of talents. It is the implementation of the strategy of "rejuvenating the country through science and education" and "powering the country with talents" and building a well-off society important guarantee. This article focuses on the issues related to the organic integration of the construction of the basiclevel party branch of college teachers and the cultivation of talents.

Keywords: College Teachers; Grassroots Party Branch; Talent Training; Organic Integration; Strategy Analysis

The college faculty party branch is the main grassroots organization of colleges and universities, and it is also an important guarantee for leading faculty and staff to complete various tasks. Colleges and universities must adhere to the socialist direction of running schools, keep in mind "what kind of people to train, how to train them, and for whom", implement the fundamental task of cultivating people with morality, speed up the high integration of the construction of teacher party branches and talent training, and then do while building a good teacher party branch, give full play to the role of teachers in talent training.

\section{The connection between the construction of the Party branch of college teachers and talent training}

\subsection{The construction of teacher party branch is an important starting point for improving the quality of talent training}

On the one hand, the party branch of college teachers should strengthen political construction and strengthen political guidance. Ideological and political education in colleges and universities is closely related to teaching and educating people, and it is also a process in which party members and cadres use words and deeds to pass on the core socialist values to students. Teachers are the main body of universities and the backbone of scientific research innovation and talent training. The construction of the Party branch of teachers must firmly grasp the national education orientation in daily teaching, and strictly prevent deviations in political direction and value orientation. First of all, colleges and universities should fundamentally follow Xi Jinping's thoughts on socialism with Chinese characteristics in the new era as party building work, focus on the demonstration of good teacher ethics and style, and guide teachers to apply correct ideas to the work of "teaching and educating

Copyright $(2020$ Zihao Li

doi: 10.18686/ahe.v4i10.2898

This is an open-access article distributed under the terms of the Creative Commons Attribution Non-Commercial License (http://creativecommons. org/licenses/by-nc/4.0/), which permits unrestricted non-commercial use, distribution, and reproduction in any medium, provided the original work is properly cited. 
people." Secondly, the end of the party building work in colleges and universities should be placed on the "education" function. It can be said that the realization of the role of university teachers' party branches as a fighting fortress depends on the extent to which party members and teachers at all levels play a leading role.

On the other hand, the Party branch of college teachers should strengthen organizational construction. Guided by the latest theoretical achievements of the party, strictly "three meetings and one lesson", and earnestly carry out the theme education activities of "two studies and one doing", "not forgetting the original intention and keeping in mind the mission" for party members and teachers, and earnestly establish party members through strict organizational construction awareness, let the teacher's party branch escort the full realization of the education function of colleges and universities. In the implementation process, it is necessary to focus on adhering to the party building ideas of "taking education as the fundamental" and "teaching as the center", inspire the centripetal force, cohesion, and creativity of the teacher's party branch, work together to improve the effectiveness of talent training, and truly realize the party training era The purpose of the newcomer's school.

\subsection{The construction of teacher party branch and the development of teacher's subjectivity complement each other}

In the process of party building, colleges and universities must give full play to the main body of the party's primary organization and teacher party members. The two complement and promote each other in party building work. Only by fully playing the role of both can improve the effectiveness of teachers' primary party building work. If college teachers want to play a role in teaching, scientific research, management and service, they must have a strong sense of responsibility, dedication and creativity. The effectiveness of party branch construction in colleges and universities relies on the role of individual party members as party members and teachers. The two are a dialectical relationship that promotes each other in party building in colleges and universities.

\section{Specific countermeasures for the organic integration of college teachers' party branch construction and talent training}

\subsection{Focus on accelerating the pace of integration of teaching and learning}

Talent training is a systematic process. Teachers need to establish the concept of lifelong learning, keep up with the times to learn the latest knowledge, and apply it to teaching, so as to truly realize the integration of "work-based learning" and "learning-based work". Specifically, working-learning is to regard the teaching process as one's own learning process, and learning to work is to regard learning as work, continuously learning and improving oneself in daily teaching, scientific planning, specific implementation, and strengthening of assessment. To achieve the organic integration of work and study, the party branch must guide teachers to learn consciously and actively, actively reflect on the work, strengthen the exchange and learning between the party member teachers of the branch and ordinary teachers, and improve the research and teaching work in the exchange of needs.

Teaching style and style of study are one of the manifestations of party style in colleges and universities. The secretary of the party branch of teachers should lead teachers to establish good learning qualities and ideological and moral cultivation. The key to the construction of the teacher party branch is to create a learning organization to achieve the integration of work and study. It is not only conducive to building a learning party branch and improving the quality of talent training, but also the core of the ideological construction of the teacher party branch. When accelerating the integration of teaching and learning, we must specifically start from four aspects: serving teachers and students, promoting talent training, subject development and cohesiveness. In terms of serving teachers and students, it is necessary to actively carry out various learning activities to enhance teachers' research and teaching capabilities, improve their ideological and moral standards, establish correct teaching concepts, build a good relationship between teachers and students, and colleagues, and then serve the teaching work. In terms of promoting talent training, we must adhere to the people-oriented principle, pay attention to humanistic care, improve the combat effectiveness and centripetal force of the teacher's party branch, cultivate students' good sense of innovation and ability in the process of teaching and educating people, and train students to be good while imparting knowledge. The moral quality of the people, and then truly cultivate high-quality talents that meet the needs of social development. In terms of discipline development, in terms of discipline construction, teaching management, and scientific research, we must adhere to the work method of combining theory with practice, innovate work concepts and models, and accelerate discipline construction. In terms of cohesive people, when carrying out ideological and political work, we must pay attention to the real emotions, fully mobilize the initiative and creativity of teachers in their work, and form a joint force to improve the centripetal force and cohesion of the party organization. 


\subsection{Adhere to the dual integration of party building work and business work}

In the new era, the teacher's party branch should, under the leadership of the secondary college's party organization, infiltrate the educated content of teachers into the construction of professional disciplines, and realize the educated construction of talents. The key to the intellectualization of talents is to put the construction of teacher ethics in a prominent position, to train excellent party members and teachers, and to ensure that the party branch secretaries are "dual leaders". When colleges and universities strengthen the construction of the teaching staff, they should achieve a high degree of unity in cultivating the learning ability, knowledge ability and innovation ability of teacher party members. Based on this, the party branch of colleges and universities should form a joint force with the teaching and research section to accelerate the development of professional disciplines. Specifically, teachers should highly unify teaching and educating people with the knowledge of teaching behavior, so that students can understand the true meaning of education in learning, and internalize them in their hearts and externalize them in action, and establish the value of the unity of knowledge and action. Secondly, we must give full play to the exemplary leading role of teacher party members, take the party's advanced nature and the construction of the learning teacher's party branch as the starting point, integrate the teaching process and the education process, and match each other, so that educators can sublimate in the transfer of knowledge Own education and outlook on life, in order to improve the self-education consciousness of college students and continuously improve the creative thinking ability of college students.

\subsection{Regarding "educating people for the party" and "educating talents for the country" as the foothold of party building in colleges and universities}

The purpose of running a university is to cultivate talents, and students are the largest group of universities, and they should give full play to the role of students in the work of grassroots party building. In the work of party building at the grassroots level in colleges and universities, we should pay attention to the radiation role of outstanding party members and teachers, do a good job in daily ideological and political education, guide students to shape a sound personality, establish a correct outlook on the world, life and values, and become a qualified socialist builder and successor. Secondly, give full play to the role of outstanding student party members, and organize various party building activities based on the actual situation and needs of students, continuously improve students' ideological and moral cultivation, team cohesion and combat effectiveness, and create an atmosphere of mutual help and growth.

Party members of college teachers are the core force of party building and teaching work, and they are also role models for students and teachers. At present, the teacher's party branch should focus on solving the problems of lack of enthusiasm for the teacher's party building work, the single form of party building activities, and the lack of a perfect assessment and incentive mechanism for party building work, and it is necessary to find a good breakthrough for teachers and students to build together. Although teachers and students are in a unity of opposites, and teachers manage and educate students, they are also a community that completes teaching tasks. In the process of teaching and scientific research, teachers and students are an inseparable unity. For students, teachers are not only the importers of knowledge and skills, but also the instructors of their learning and life. They need the affirmation and support, understanding and care of teachers. Therefore, as a party member teacher, we must formulate a sound teaching plan based on the actual situation. In the party building work, we must pay more attention to the talent training plan. Through the joint construction of teachers and students, do a good job in party building, discipline construction and talent training in colleges and universities, and promote various colleges the work develops well and quickly.

\section{Conclusion}

To sum up, the construction of the party branch of college teachers is a long, systematic and complex process, which has an important relationship with the discipline construction and talent training of colleges and universities. Colleges and universities should correctly recognize the importance of party building at the grassroots level, actively change their thinking, innovate work models, and strengthen the connection with teaching and scientific research. While improving the efficiency and quality of party building at the grassroots level, they should also be able to do a good job in personnel training and promote The overall healthy development of universities.

\section{References}

1. Li S, Wang Y, Mai X. Discussion on the construction of college teachers' party branch and its role. Party History Wenyuan 2015; (008): 44-47.

2. Chen P. Exploration and analysis of the construction of learning party branches for college teachers. China Electric Power Education 2013; (9): 187-188. 